NASA/TM—2008-215454

\title{
Processing and Preparation of Advanced Stirling Convertors for Extended Operation at NASA Glenn Research Center
}

Salvatore M. Oriti and Peggy A. Cornell

Glenn Research Center, Cleveland, Ohio 


\section{NASA STI Program . . . in Profile}

Since its founding, NASA has been dedicated to the advancement of aeronautics and space science. The NASA Scientific and Technical Information (STI) program plays a key part in helping NASA maintain this important role.

The NASA STI Program operates under the auspices of the Agency Chief Information Officer. It collects, organizes, provides for archiving, and disseminates NASA's STI. The NASA STI program provides access to the NASA Aeronautics and Space Database and its public interface, the NASA Technical Reports Server, thus providing one of the largest collections of aeronautical and space science STI in the world. Results are published in both non-NASA channels and by NASA in the NASA STI Report Series, which includes the following report types:

- TECHNICAL PUBLICATION. Reports of completed research or a major significant phase of research that present the results of NASA programs and include extensive data or theoretical analysis. Includes compilations of significant scientific and technical data and information deemed to be of continuing reference value. NASA counterpart of peer-reviewed formal professional papers but has less stringent limitations on manuscript length and extent of graphic presentations.

- TECHNICAL MEMORANDUM. Scientific and technical findings that are preliminary or of specialized interest, e.g., quick release reports, working papers, and bibliographies that contain minimal annotation. Does not contain extensive analysis.

- CONTRACTOR REPORT. Scientific and technical findings by NASA-sponsored contractors and grantees.

- CONFERENCE PUBLICATION. Collected papers from scientific and technical conferences, symposia, seminars, or other meetings sponsored or cosponsored by NASA.

- SPECIAL PUBLICATION. Scientific, technical, or historical information from NASA programs, projects, and missions, often concerned with subjects having substantial public interest.

- TECHNICAL TRANSLATION. Englishlanguage translations of foreign scientific and technical material pertinent to NASA's mission.

Specialized services also include creating custom thesauri, building customized databases, organizing and publishing research results.

For more information about the NASA STI program, see the following:

- Access the NASA STI program home page at http://www.sti.nasa.gov

- E-mail your question via the Internet to help@ sti.nasa.gov

- Fax your question to the NASA STI Help Desk at 301-621-0134

- Telephone the NASA STI Help Desk at 301-621-0390

- Write to: NASA Center for AeroSpace Information (CASI) 7115 Standard Drive Hanover, MD 21076-1320 
NASA/TM-2008-215454

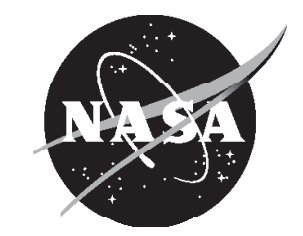

\section{Processing and Preparation of Advanced Stirling Convertors for Extended Operation at NASA Glenn Research Center}

Salvatore M. Oriti and Peggy A. Cornell

Glenn Research Center, Cleveland, Ohio

Prepared for the

Sixth International Energy Conversion Engineering Conference (IECEC)

sponsored by the American Institute of Aeronautics and Astronautics

Cleveland, Ohio, July 28-30, 2008

National Aeronautics and

Space Administration

Glenn Research Center

Cleveland, Ohio 44135 


\section{Acknowledgments}

The work described in this paper was performed for the Science Mission Directorate (SMD) and the Radioisotope Power System (RPS) Project, which provided funding for these projects.

Trade names and trademarks are used in this report for identification only. Their usage does not constitute an official endorsement, either expressed or implied, by the National Aeronautics and Space Administration.

Level of Review: This material has been technically reviewed by technical management.

Available from

NASA Center for Aerospace Information 7115 Standard Drive

Hanover, MD 21076-1320
National Technical Information Service 5285 Port Royal Road Springfield, VA 22161

Available electronically at http://gltrs.grc.nasa.gov 


\title{
Processing and Preparation of Advanced Stirling Convertors for Extended Operation at NASA Glenn Research Center
}

\author{
Salvatore M. Oriti and Peggy A. Cornell \\ National Aeronautics and Space Administration \\ Glenn Research Center \\ Cleveland, Ohio 44135
}

\begin{abstract}
The U.S. Department of Energy (DOE), Lockheed Martin Space Company (LMSC), Sunpower Inc., and NASA Glenn Research Center (GRC) have been developing an Advanced Stirling Radioisotope Generator (ASRG) for use as a power system on space science missions. This generator will make use of the free-piston Stirling convertors to achieve higher conversion efficiency than currently available alternatives. NASA GRC is supporting the development of the ASRG by providing extended operation of several Sunpower Inc. Advanced Stirling Convertors (ASCs). In the past year and a half, eight ASCs have operated in continuous, unattended mode in both air and thermal vacuum environments. Hardware, software, and procedures were developed to prepare each convertor for extended operation with intended durations on the order of tens of thousands of hours. Steps taken to prepare a convertor for long-term operation included geometry measurements, thermocouple instrumentation, evaluation of working fluid purity, evacuation with bakeout, and high purity charge. Actions were also taken to ensure the reliability of support systems, such as data acquisition and automated shutdown checkouts. Once a convertor completed these steps, it underwent short-term testing to gather baseline performance data before initiating extended operation. These tests included insulation thermal loss characterization, low-temperature checkout, and fulltemperature and power demonstration. This paper discusses the facilities developed to support continuous, unattended operation, and the processing results of the eight ASCs currently on test.
\end{abstract}

\section{Nomenclature}

$\begin{array}{ll}\text { A }_{\text {rms }} & \text { RMS ampere } \\ \text { ASC } & \text { Advanced Stirling Convertor } \\ \text { ASRG } & \text { Advanced Stirling Radioisotope Generator } \\ \text { DOE } & \text { Department of Energy } \\ \text { FPC } & \text { Failsafe Protection Circuit } \\ \text { GPHS } & \text { General Purpose Heat Source } \\ \text { GRC } & \text { Glenn Research Center } \\ \text { LMSC } & \text { Lockheed Martin Space Company } \\ \text { M/Z } & \text { Mass to charge ratio } \\ \text { MPa } & \text { Megapascal } \\ \text { NASA } & \text { National Aeronautics and Space Administration } \\ \text { Q }_{\text {loss }} & \text { Thermal power lost to environment through insulation } \\ \text { PID } & \text { Proportional, Integral, Derivative } \\ \text { RGA } & \text { Residual Gas Analyzer } \\ \text { RTG } & \text { Radioisotope Thermoelectric Generator } \\ \mathrm{T}_{\mathrm{H}} & \text { Hot-end temperature } \\ \mathrm{T}_{\mathrm{C}} & \text { Rejection temperature } \\ \text { TDC } & \text { Technology Demonstration Convertor } \\ \mathrm{V}_{\text {rms }} & \text { RMS volt } \\ \mathrm{W}_{\mathrm{e}} & \text { Watt, electrical } \\ \mathrm{W}_{\mathrm{T}} & \text { West temperature ratio } \\ \mathrm{W}_{\text {th }} & \text { Watt, thermal } \\ & \end{array}$




\section{Introduction}

Lockheed Martin Space Company (LMSC) was selected as the system integration contractor by the Department of Energy (DOE) to develop a radioisotope-powered generator for potential use on space science missions (ref. 1). This generator will utilize Advanced Stirling Convertors (ASC) to convert heat from a radioisotope heat source into electricity, and thus has been named the Advanced Stirling Radioisotope Generator (ASRG). Stirling power conversion offers an increase in efficiency over Radioisotope Thermoelectric Generators (RTGs), requiring one fourth the amount of radioisotope fuel for the same power output (ref. 1). LMSC's design of the ASRG engineering unit is shown in figure 1. The engineering unit will use electric heaters to simulate the Plutonium-238 General Purpose Heat Source (GPHS) modules used in flight. One heat source is conductively coupled to the hot end on each ASC. The rectangular housing sections act as a radiator to reject the waste heat of the Stirling cycle from each ASC. A flange on each ASC provides a heat conduction path from the convertor to the housing. Some candidate missions may require continuous operation of the power system for up to 14 years, with an additional 3 years of operation required during storage prior to launch. Because of this long life requirement, several experiments have been initiated at GRC to demonstrate life and reliability of the ASC (refs. 2 and 3). One testing technique implemented involves continuous, unattended convertor operation to gather performance data for thousands of hours. This extended operation allows observation of convertor performance trends over a sufficient length of time to investigate any potential degradation.

This paper describes preparation and baseline testing of eight convertors that began extended operation within the last year and a half. The eight convertors comprise three different ASC designs, as summarized in table I. ASC0s have Inconel 718 (Special Metals Corporation) heater heads with a maximum hot-end temperature of $650{ }^{\circ} \mathrm{C}$ while ASC-1HSs and ASC-1s have MarM-247 heater heads with a maximum hot-end temperature of $850{ }^{\circ} \mathrm{C}$. The ASC-0s and ASC-1HSs were hermetically sealed with their helium fill tubes left unsealed and connected to an isolation valve to permit sampling of the working fluid during extended operation. ASC-1s use MarM-247 heater heads, also operating up to a hot-end temperature of $850^{\circ} \mathrm{C}$, but were not hermetically sealed.

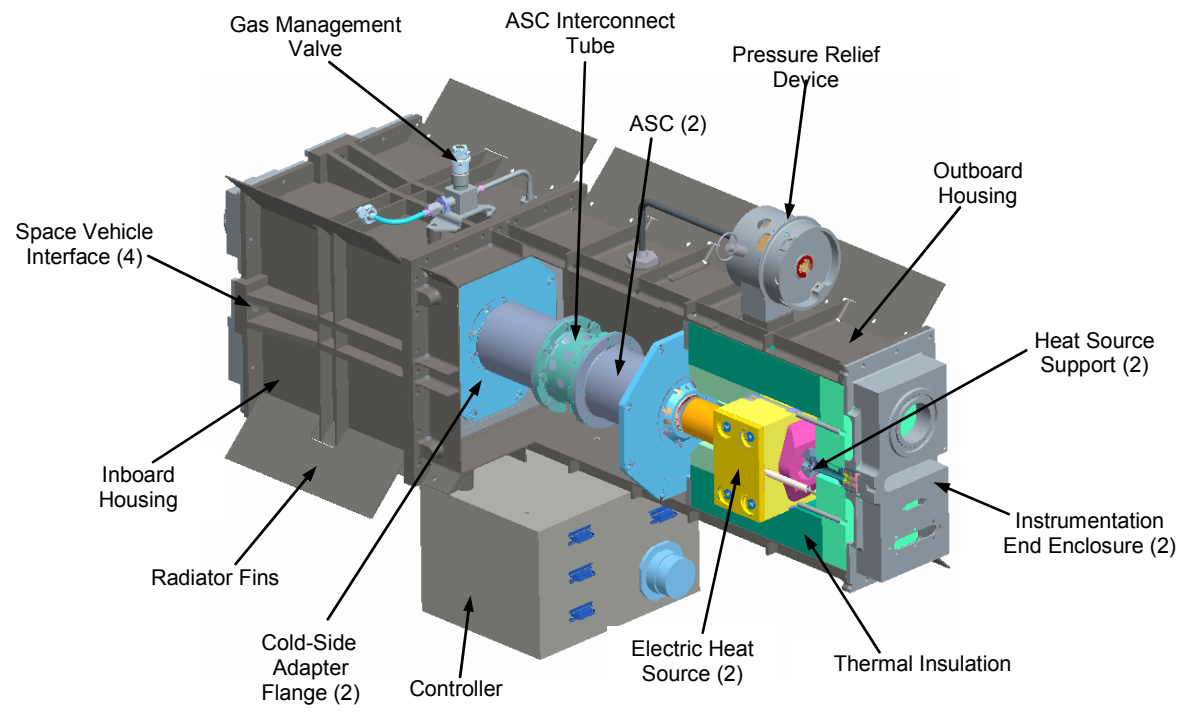

Figure 1._LMSC Advanced Stirling Radioisotope Generator Engineering Unit. Image c.o. Lockheed Martin Space Systems.

TABLE I.-SUMMARY OF ASCS TESTED AT GRC

\begin{tabular}{|l|c|c|c|}
\hline \multicolumn{1}{|c|}{ Convertor designation } & Heater head material & Hermetic & $\begin{array}{c}\text { Hot-end temperature, } \\
{ }^{\circ} \mathrm{C}\end{array}$ \\
\hline ASC-1 $\# 3$ and $\# 4$ & MarM-247 & No & 850 \\
\hline ASC- $0 \# 1, \# 2, \# 3$, and $\# 4$ & Inconel 718 & Yes & 650 \\
\hline ASC-1HS $\# 1$ and $\# 2$ & MarM-247 & Yes & 850 \\
\hline
\end{tabular}



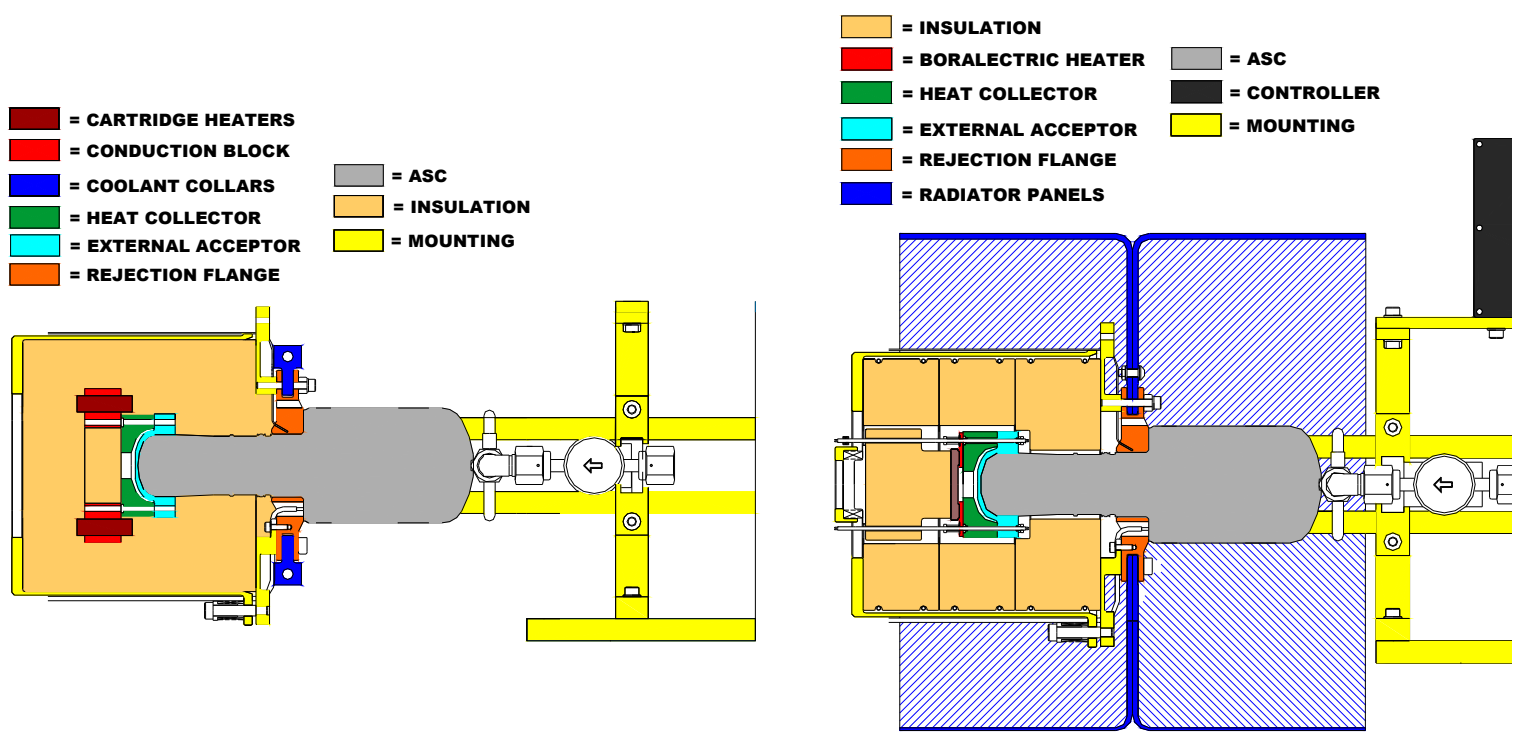

Figure 2.-ASC-0 and ASC-1HS configurations. Convertors were designed to permit different heating and cooling devices for in-air (left) and thermal vacuum (right) operation.

Chronologically, the ASC-1 design pre-dates the ASC-0 and ASC-1HS designs. The ASC-1 was developed during Phase II of the convertor development project (NAS3-03128) (ref. 7). Phase III of the project was expanded to include production of the ASC-0s and ASC-1HSs, which were based on the ASC-1 design but included hermetic sealing. These convertors were designed for operation in both air and thermal vacuum environments. A heat collector has been brazed to the hot end of the heater head, allowing attachment of a cartridge heater or Boralectric (GE Advanced Ceramics) source. A copper flange has been brazed to the rejection zone of the heater head that allows attachment of a cooling mechanism. For in-air operation, coolant loops are attached to the flanges which are then replaced by radiator panels for thermal vacuum operation. The in-air and thermal vacuum configurations are depicted in figure 2.

\section{Extended Operation Test Stations}

Capability for continuous, unattended operation of Stirling convertors was developed at GRC in 2003 to support Technology Demonstration Convertor (TDC) testing during the $110 \mathrm{We}$ SRG project (ref. 5). The project was redirected in May 2006 to increase specific power by incorporating ASC technology (ref. 1). The knowledge and experience acquired during TDC testing was reapplied for ASC testing. The Stirling Research Laboratory at GRC contains four test stations dedicated to ASC operation. A total of eight ASCs may be operated simultaneously; three pairs in-air and a fourth pair in thermal vacuum. Each test station includes an operations rack, gas management system, cold-end circulator, and convertor pair of interest. A test station with an ASC-0 pair is shown in figure 3. Each operations rack consists of the data system, hard-wired failsafe protection devices, hot-end temperature control system, transducers, and convertor controller with load.

The data system was developed using National Instruments software and hardware. The software was developed using LabVIEW (National Instruments Corporation) and is capable of controlling the support systems without user intervention. The user may specify upper and lower limits for any parameter monitored by the data system. The software will safely shut down operation of the convertor pair when an out-of-limit condition is sensed. Parameters that may trigger a shut down include: hot-end and rejection temperatures, convertor mean charge pressure, piston amplitude of oscillation, and loss of building power. The data system software is capable of controlling test station hardware such as the cold-end circulator, the hot-end temperature set points, and the load. Each of these systems is connected to the data system software by a serial communication link. Hard-wired protection devices were also installed in the operations rack that function independent of the software-based protection. The hot-end temperature of each convertor is monitored by a limit controller. If either hot-end temperature exceeds the user-defined limit, the limit controller removes heater power from both convertors via a relay. Also, a failsafe protection circuit (FPC) was implemented to prevent piston over-stroke. The FPC is capable of monitoring up to five input signals. Each input has an associated, user adjustable set point. When any signal exceeds its set point, an emergency load is applied 


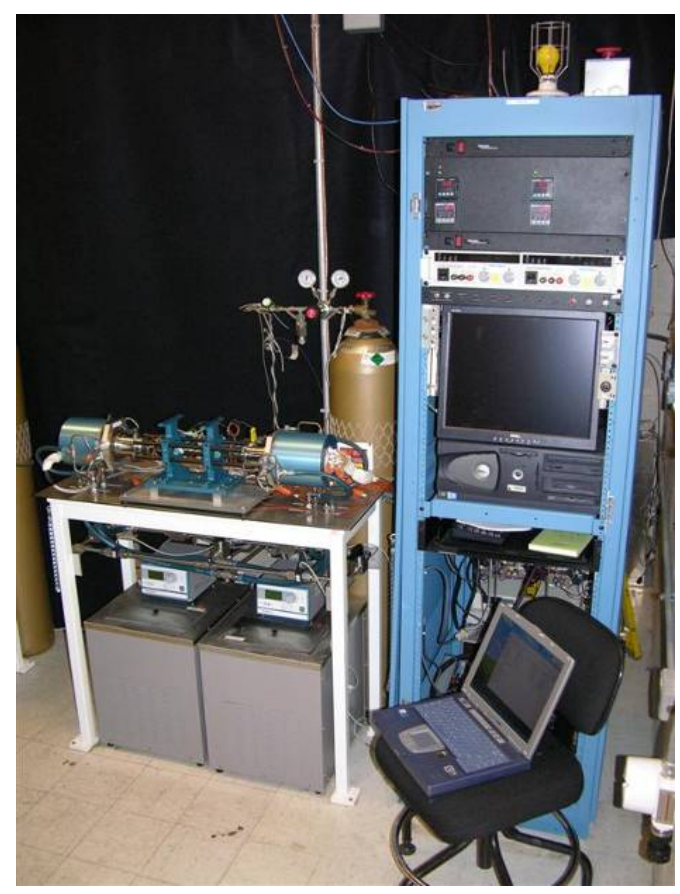

Figure 1.-Extended operation test station.

across both alternators in less than one half of a cycle. Piston position sensor signals are the primary input. However, other signals may also be used, such as accelerometer or alternator voltage.

Hot-end temperature control is accomplished by use of programmable DC power supplies driven by closed-loop proportional-integral-derivative (PID) controllers. Each convertor hot-end temperature is controlled individually.

Heater power input and alternator power output are measured using root-mean-square (RMS) voltage, current and power transducers. The transducers output signals ranging from 0 to $5 \mathrm{~V}$ to the data system.

The helium management system (fig. 4) serves the functions of convertor evacuation during bakeout, evacuation of helium supply lines, charge pressure adjustment, and sampling of the convertor working fluid. The helium working fluid can be accessed through the fill tube and isolation valve. The isolation valves (V7 and V8) permit disconnection of a convertor from the test stand without sacrificing its high purity charge. During a bakeout, the convertors are evacuated using the pumping station. The pumping station is also used to evacuate the helium supply line back to the bottle valve. This produces an ultra high purity environment when supplying helium to the convertors during charge pressure adjustment procedures. During extended operation, the convertors are connected to a helium management system with the isolation valves open (V7 and V8 of figure 4), with the working fluid occupying the volumes up to V9 and V10. The remainder of the system is kept at ultra high vacuum around 5e-8 torr. This permits measurement of the mean convertor pressure by the pressure transducers, and also allows sampling of the helium working fluid through variable leak valves V11 and V12. Orifices (OR1 and OR2) located on the inlet fitting of each isolation valve prevent bounce space pressure wave communication to the manifold. The system contains a residual gas analyzer (RGA) used to observe species present in the vacuum generated by the pumping station. When performing a bakeout, it records species emanating from the convertors. When introducing helium to the convertors, either for backfill or charge pressure adjustment, it records the background vacuum spectrum generated before introducing helium from the supply. This is done to ensure no undesirable species, such as air or organics, are present in the supply plumbing. A sample of the bottle helium may also be introduced to the RGA to ensure the bottle has not been contaminated. When sampling the convertor helium working fluid during extended operation, a small amount of helium from each convertor is separately introduced to the RGA through the variable leak valves.

All test stations described in this paper orient a pair of convertors in the dual-opposed configuration with the heater heads facing outward. This configuration provides dynamic balance because the piston motions are equal but opposite in direction. This is also the orientation of the convertor pair in the ASRG.

Procedures for test station setup, checkout, and validation have been developed to ensure proper function throughout the life of a test. These procedures are summarized in table II. The purpose of this procedure set is to standardize the process for test station preparation and to validate the safety of operation and integrity of data. 

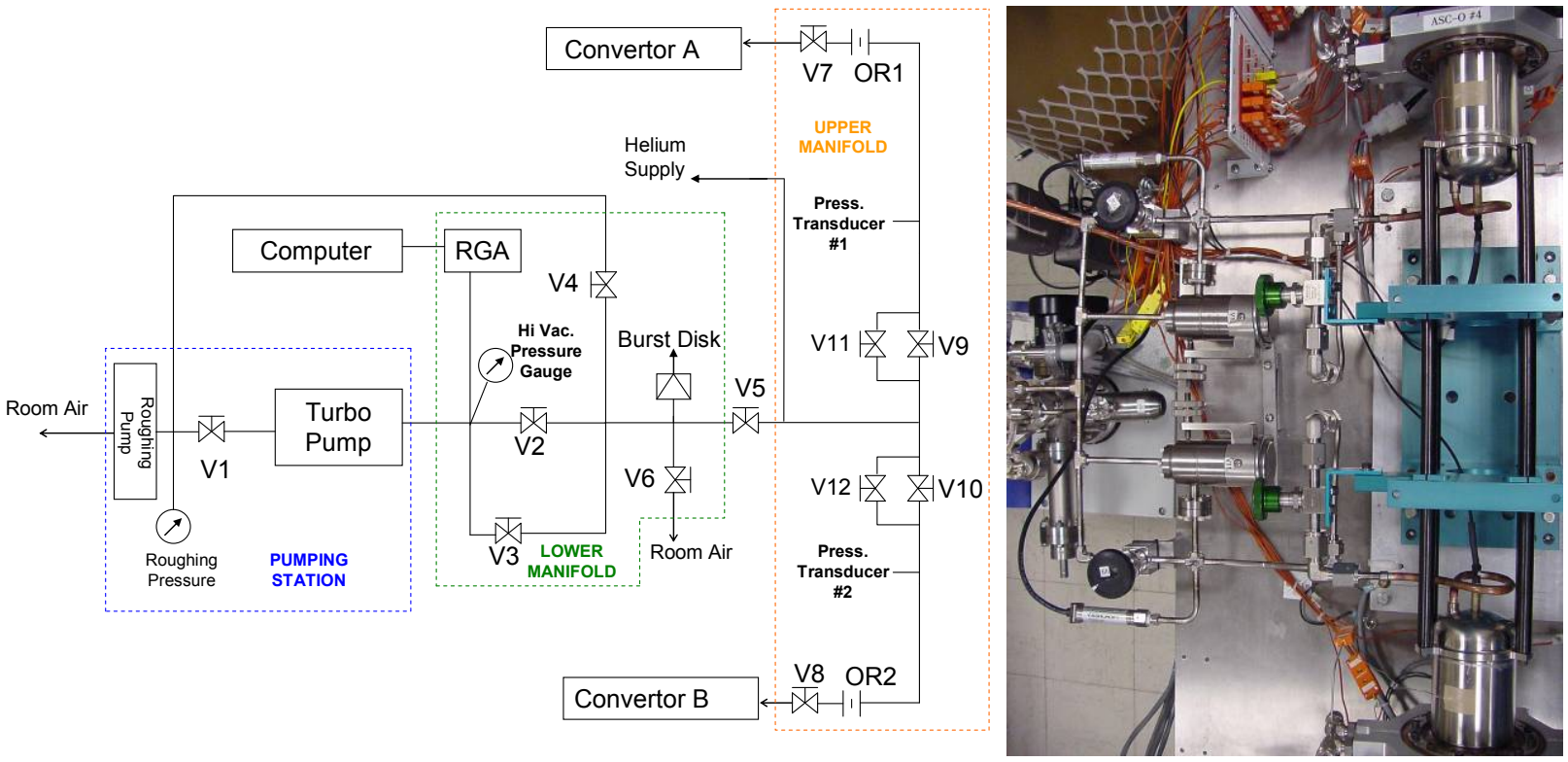

Figure 4.-Helium management system. System schematic (left) and photograph of upper manifold on support stand (right).

TABLE II.-PROCEDURES FOR TEST STATION SETUP, CHECKOUT, AND VALIDATION

\begin{tabular}{|c|l|l|}
\hline Procedure no. & \multicolumn{1}{|c|}{ Title } & \multicolumn{1}{|c|}{ Description } \\
\hline P80-006 & $\begin{array}{l}\text { Setup Checklist for Operating the } \\
\text { ASC }\end{array}$ & $\begin{array}{l}\text { Provides instructions for ensuring electrical connections, rack power up } \\
\text { sequence, data system software initialization, circulator initialization, and hot- } \\
\text { end temperature control loop initialization. Intended for execution any time a } \\
\text { convertor is being brought to operation from the idle state. }\end{array}$ \\
\hline P80-023 & $\begin{array}{l}\text { Instrumentation Rack Checkout } \\
\text { Procedure for the ASC }\end{array}$ & $\begin{array}{l}\text { Provides instructions for verifying all wiring and connections inside operations } \\
\text { rack such as data system modules, voltage, current, and power transducers, } \\
\text { pressure transducers, piston position sensor and processor, thermocouples, and } \\
\text { hard-wired protections. Intended for execution any time a hardware change is } \\
\text { made to the operations rack. }\end{array}$ \\
\hline P80-024 & $\begin{array}{l}\text { Rack Unattended Operation } \\
\text { Check-out Procedure }\end{array}$ & $\begin{array}{l}\text { Provides instructions to verify data system software execution of shutdowns. } \\
\text { reaction of the data system software. }\end{array}$ \\
\hline P80-026 & $\begin{array}{l}\text { Protection Circuit Setup and } \\
\text { Adjustment for the ASC }\end{array}$ & $\begin{array}{l}\text { Provides instructions to properly adjust the failsafe protection circuit. This } \\
\text { ensures the circuit will engage only if the piston amplitude exceeds a user } \\
\text { defined margin above nominal, and not during normal operation. }\end{array}$ \\
\hline
\end{tabular}

\section{Convertor Setup and Bakeout}

After delivery to GRC, each convertor pair went through several steps prior to operation. These steps included photographic documentation, thermocouple installation, integration into support hardware, bakeout, and high purity helium charge. The procedures evolved as each pair was processed to make improvements based on prior experiences and newly acquired information. Therefore, the processing described hereafter will not be completely uniform amongst all convertor pairs.

Thermocouple instrumentation included those measuring the convertor hot-end and rejection temperatures. Thermocouple probes, usually with an Inconel (Special Metals Corporation) sheath, were chosen for these locations because of their high temperature capability and robustness. The hot-end and rejection thermocouples were installed by inserting the probes into the thermal wells and strapping the sheath to a surface Nickel ribbon at several locations along their length (fig. 7). This attachment method provided robustness and reliability at the high temperature present at the convertor hot end. Up to eight thermocouples were used to monitor the hot-end temperature and two were used to monitor the rejection temperature. The pressure vessel temperatures were monitored by adhesivebacked surface mount thermocouples.

A bakeout was performed after each convertor had been completely set up on a station. Many organics can outgas and could have an undesirable effect on convertor performance when introduced into the working fluid. The bakeout process removed water and volatile substances by drawing a vacuum on the convertor volume while raising 
its temperature. This is the same practice used in most vacuum systems. Raising the temperature of the vessel accelerates the evolution of water or other substances so that they may more quickly be removed by the vacuum system. This general approach has been applied to convertor bakeout, with the elevated temperature limited by the alternator magnets.

Different bakeout versions have been used amongst the four convertor pairs. ASC- $0 \# 1$ and $\# 2$ underwent a short bakeout of about three days consisting solely of evacuation with limited temperature application. In the case of the ASC-1s, the process was hindered by their O-ring seals. When evacuating these convertors, the ultimate pressure attained was significantly higher than that of the hermetic convertors, and a truncated version of the bakeout process was used.

An enhanced bakeout process was performed on ASC-0 \#3 and \#4 and ASC-1HSs incorporating stages of operation interstitial with stages of evacuation at elevated temperature. The process is summarized by the flowchart in figure 5 and functions as follows. After a convertor pair is connected to the helium management system, the plumbing up to the isolation valves is evacuated. This process includes a bakeout of the lines so that no impurities exist that could contaminate the attached convertors. The process next includes a provision to sample the as delivered convertor helium charge to evaluate the necessity of bakeout. However, this was determined to produce erroneous conclusions, as will be discussed in the ASC-1HS section. If bakeout is deemed necessary, the evacuation begins.

After establishing convertor vacuum, the baseline pressure and RGA spectrum are recorded during initial evacuation with the convertors at ambient temperature. Heat is then applied to raise the convertor temperature to $80^{\circ} \mathrm{C}$. The convertors are filled with helium then operated at $500{ }^{\circ} \mathrm{C}$ hot end and $80^{\circ} \mathrm{C}$ rejection. After the operation stage, the convertors are re-evacuated while being heated to $80^{\circ} \mathrm{C}$. Bakeout is concluded once the pressure and RGA spectrum indicate a sufficiently pure environment has been established inside the convertors. Some metrics for this conclusion include total pressure, presence of organics, and presence of oxygen. Generally, bakeout is concluded when the total pressure reaches its asymptotic limit, as interpolated from a pressure vs. time plot. Once bakeout has been concluded, heat is removed and the convertors are allowed to cool back to ambient temperature. The RGA spectrum is recorded at this point as well for comparison to the baseline ambient temperature spectrum recorded at the onset of bakeout.

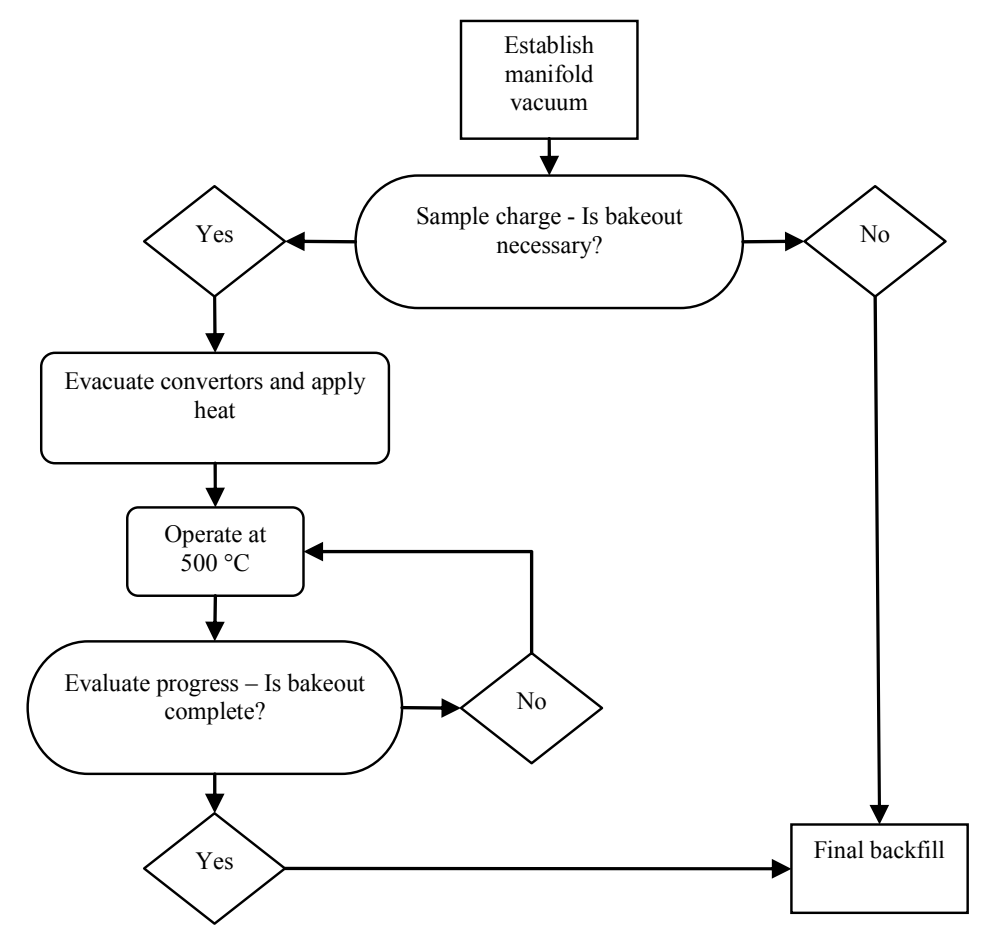

Figure 2.-Revised bakeout procedure flowchart. 
The intent of this process was to accelerate removal of substances from deep within the convertor, such as inner displacer volume, that would be nearly impossible to reach by drawing a vacuum alone. This is a typical problem encountered in any vacuum environment. Once the gas pressure falls below 1e-4 torr, laminar flow effects are almost completely eliminated, and the gas motion becomes free molecular. In this regime, atoms or molecules of gas do not interact enough to influence each other. Rather, the interactions with the volume's containment are far more frequent. Thus, gas molecules separated from a pump by small passages are difficult to remove. Such is the case for gas inside the displacer of the ASC. To be removed from this volume, the molecules would have to pass through a series of orifices and close clearance seals, such as the displacer vent and the clearance around the piston. The introduction and removal of helium during the bakeout process improves the ability to remove evolved species by carrying them out via laminar flow.

\section{A. ASC-0 \#1 and \#2}

The first pair of hermetic convertors (ASC-0 \#1 and \#2) was delivered to GRC in December 2006. Prior to delivery, \#1 operated for $277 \mathrm{hr}$ and \#2 operated for $281 \mathrm{hr}$. The bakeout process lasted approximately four days. After initiating evacuation of both convertors the pressure was $5 \mathrm{e}-5$ torr. Using the heat sources and coolant loops, the convertors were heated to about $70{ }^{\circ} \mathrm{C}$ for approximately $9 \mathrm{hr}$. After returning to ambient temperature the pressure was 3.1e-7 torr; a reduction of more than two decades. RGA spectra from each convertor were collected to assess the cleanliness (fig. 6). As would be expected, the dominant feature in each convertor was water, occurring at $\mathrm{M} / \mathrm{Z}=18$, with partial pressure of water in $\# 2$ approximately 16 percent higher than that of $\# 1$. There was also trace evidence of air, indicated by peaks at $\mathrm{M} / \mathrm{Z}=28$ (nitrogen), $\mathrm{M} / \mathrm{Z}=32$ (oxygen), and $\mathrm{M} / \mathrm{Z}=44$ (carbon dioxide). No evidence of other species was present. The total pressures and levels of species after bakeout were comparable to those realized after bakeouts of other convertors to date (ref. 3), thus this environment was deemed sufficiently clean to proceed.

\section{B. ASC-0 \#3 and \#4}

The second pair of hermetic convertors (ASC-0 \#3 and \#4) was delivered to GRC in July 2007. Prior to delivery, \#3 operated for $97 \mathrm{hr}$ and \#4 operated for $93 \mathrm{hr}$. A total of twelve thermocouples were installed on each hot end (fig. 7), and two on each rejection flange. Eight thermocouples were installed in the external heat acceptor to monitor convertor hot-end temperature. Two rows of four thermocouples were placed around the circumference. This configuration was chosen to permit measurement of the axial gradient along the heat input zone of the heater head. Also, four thermocouples were installed on the face of the heat collector. These were placed to monitor heat source temperature. Two thermocouples were installed in the root of the rejection flange to monitor rejection temperature.

The bakeout process lasted 39 days. When convertor vacuum was first established at ambient temperature, the pressure was 1.6e-5 torr. After the entirety of the bakeout effort and thermal loss test, the pressure at room temperature was $3.3 \mathrm{e}-8$ torr. The net effect of the bakeout is illustrated in figure 8 . Between these two points in time, a total of three operation stages were completed in addition to the thermal loss characterization. The total pressure was reduced by almost three decades. The amount of water $(\mathrm{M} / \mathrm{Z}=18)$ was reduced by over 2 decades. Helium $(\mathrm{M} / \mathrm{Z}=4)$, oxygen $(\mathrm{M} / \mathrm{Z}=32)$ and carbon dioxide $(\mathrm{M} / \mathrm{Z}=44)$ were reduced to undetectable levels. These results confirmed that the revised bakeout process was effective at purifying the internal convertor volume.
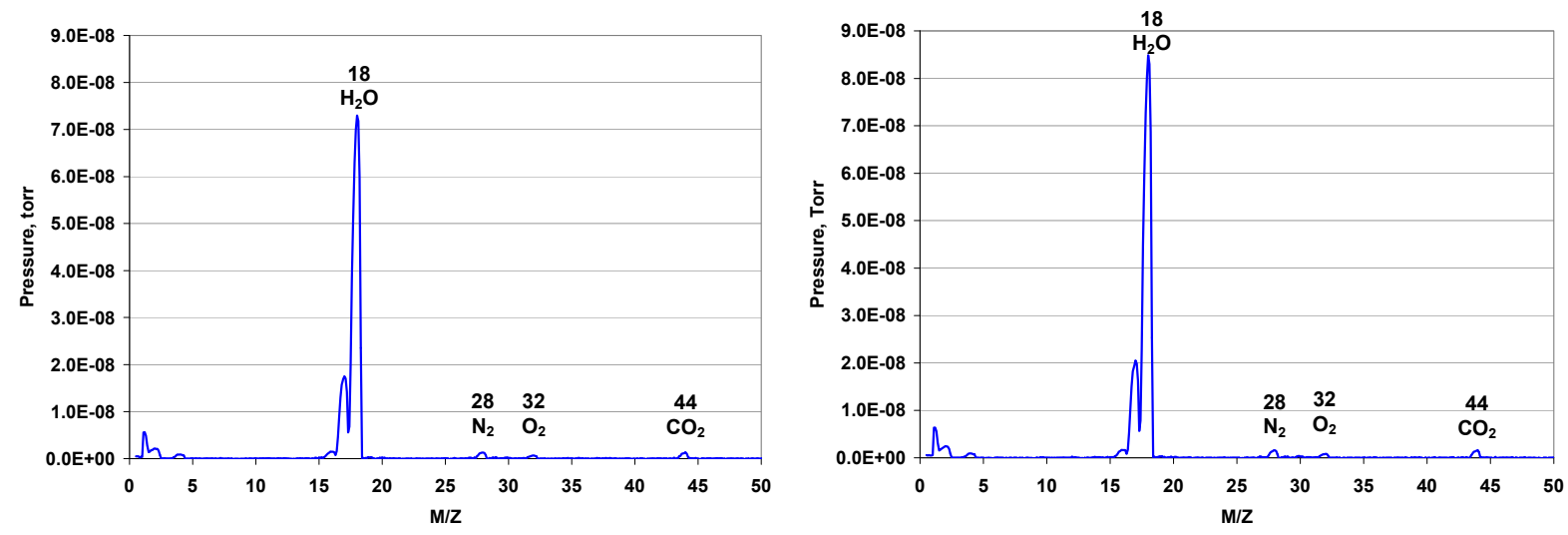

Figure 3.-ASC-0 \#1 (left) and \#2 (right) RGA spectra after bakeout. 


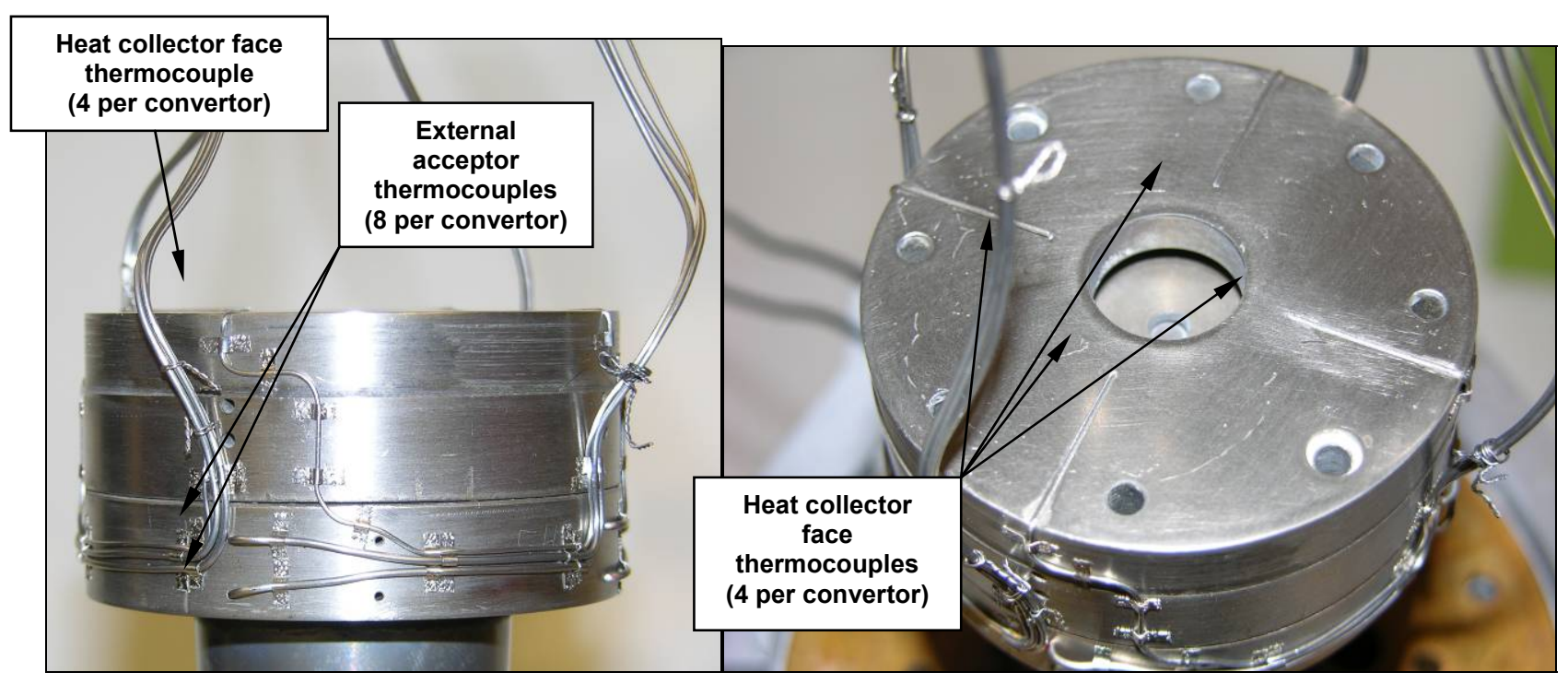

Figure 4.-ASC-0 \#3 and \#4 hot-end thermocouple installation.

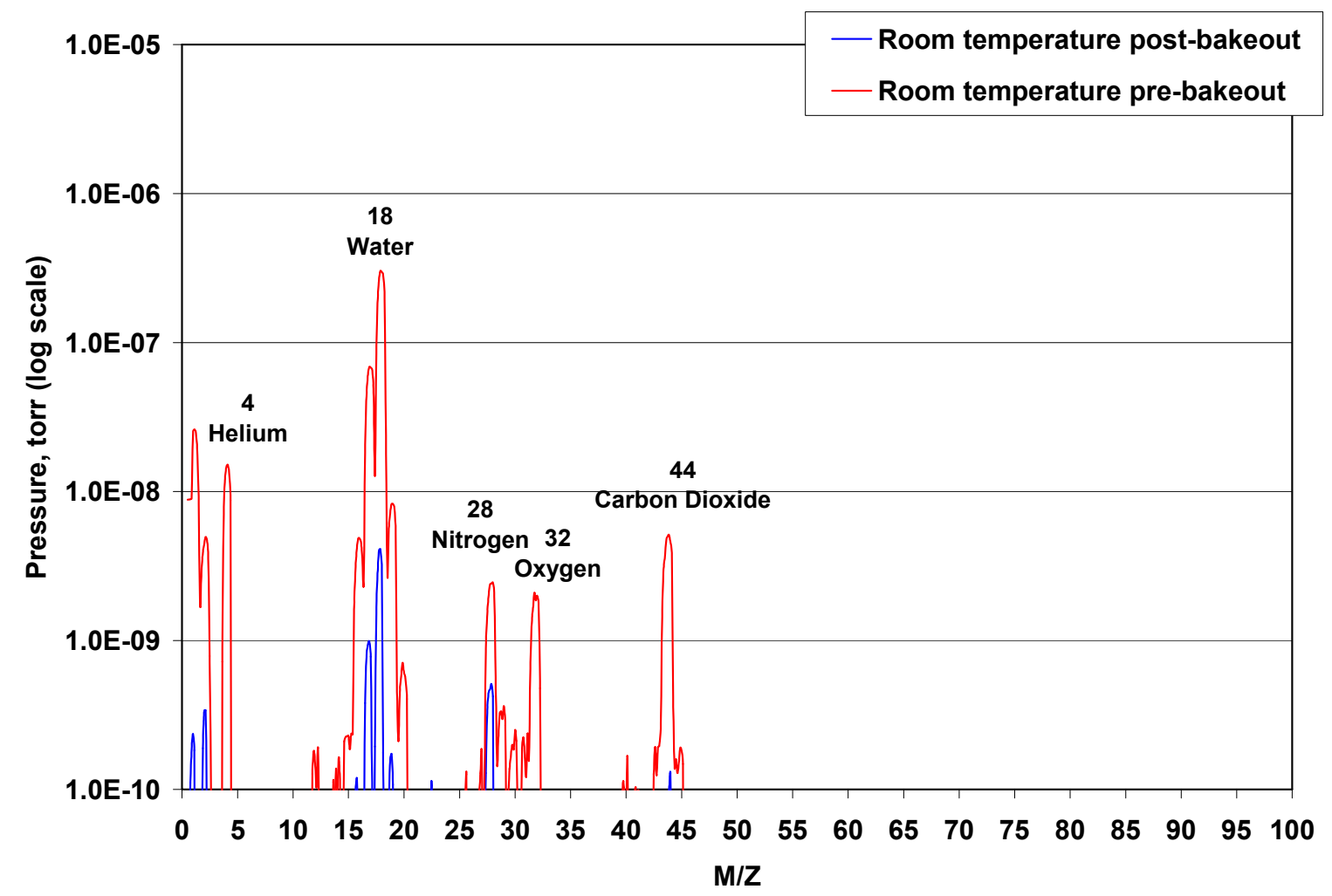

Figure 5.-ASC-0 \#3 and \#4 pre and post bakeout room temperature RGA spectra.

\section{ASC-1HS \#1 and \#2}

The third pair of hermetic convertors (ASC-1HS \#1 and \#2) was delivered to GRC in November 2007. Prior to delivery, \#1 operated for $326 \mathrm{hr}$ and \#2 operated for $324 \mathrm{hr}$. Following delivery, the convertors underwent heater head diameter measurement to support validation of structural models. The methodology involves precisely measuring the initial geometry, then measuring again after the heater head has been exposed to some time at temperature and pressure. The measurement device consisted of a laser source and detector. The diameter of each convertor heater head was measured at several axial and circumferential locations to produce a three dimensional 
representation. This technique was precise (on the order of $1 \mathrm{e}-5 \mathrm{in}$.), such that care had to be taken so that seemingly innocuous parameters would not interfere with evaluation of creep strains. During subsequent measurements, the temperature of the object must be noted, since thermal expansion may cause strains that could be falsely interpreted as creep. The internal pressure at the time of measurement was also noted, and must be accounted for since it may produce deflections. Oxidation layers on the outer diameter of the heater head may also introduce error.

Following heater head geometry measurements, the convertors underwent thermocouple installation in the same fashion described in the previous section on ASC-0 \#3 and \#4. Additional thermocouples were installed along the heater head wall to support thermal model validation. It has been proposed that the actual temperature gradient along the heater head differs from that predicted by a conduction model because of the cooling provided by the regenerator. Three thermocouple probes were attached to each heater head wall using a high temperature ceramic adhesive (fig. 9). Two thermocouple probes were placed diametrically opposed near the mid-point of the heater head regenerator section. The third thermocouple was placed near the midpoint of the tapered wall section closer to the hot-end. The thermocouple sheaths were routed up towards the hot end and joined the thermocouple bundles there.

The as-delivered helium charge was then evaluated for purity. Observation of these samples revealed that a significant time was required for the convertor gas to mix with volume at the inlet of the leak valves. The first sample taken from convertor \#1 showed the only impurity being nitrogen. During the next $107 \mathrm{hr}$ of mixing, five more samples were taken. The second and third samples indicated a spontaneous rise in the nitrogen level even though no convertor activity had taken place. During this time, the convertor simply remained idle at room temperature with its isolation valve open to the upper manifold. This suggested that more time was required to be certain the convertor gas had reached the inlet of the leak valve. Three more samples were taken and these indicated the nitrogen level had leveled off. This was interpreted as the completion of mixing of the two volumes. It can be estimated from these data that gas mixing by diffusion between the convertor and upper manifold requires at least $48 \mathrm{hr}$ to reach equilibrium. This is an important effect to appreciate so that samples are not taken immediately after a convertor is connected to the system, as this could produce erroneous data. It was discovered that simply sampling the as-delivered helium charge to evaluate convertor purity may be inadequate. This can be illustrated by comparing the RGA spectrum of the last helium sample taken before evacuating to that taken just after initiating evacuation (fig. 10). After evacuating \#1 for over $18 \mathrm{hr}$, the spectrum showed high levels of water $(\mathrm{M} / \mathrm{Z}=18$ ) with a total pressure of 9.6e-7 torr. Compared to the end state of bakeouts performed on other convertors, it was obvious that the convertors were not as purified, but the as-delivered helium samples did not show this. The as-delivered helium

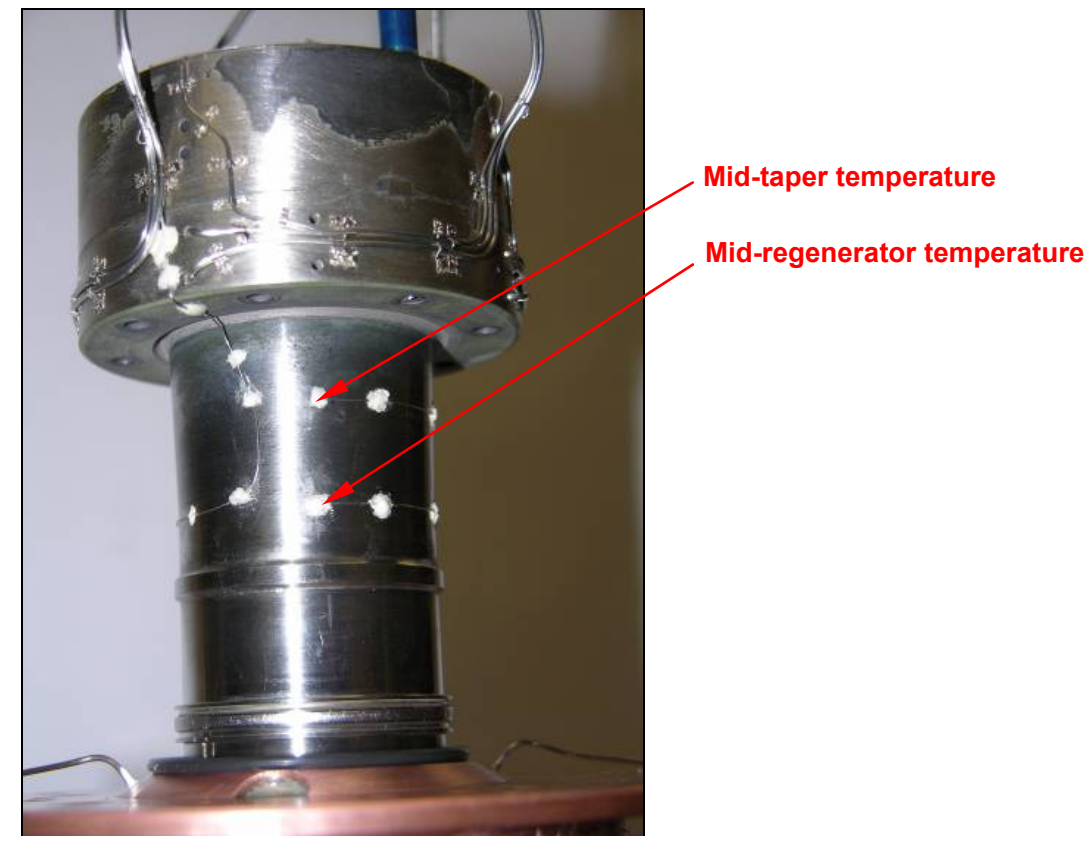

Figure 6.-ASC-1HS heater head wall thermocouples. 

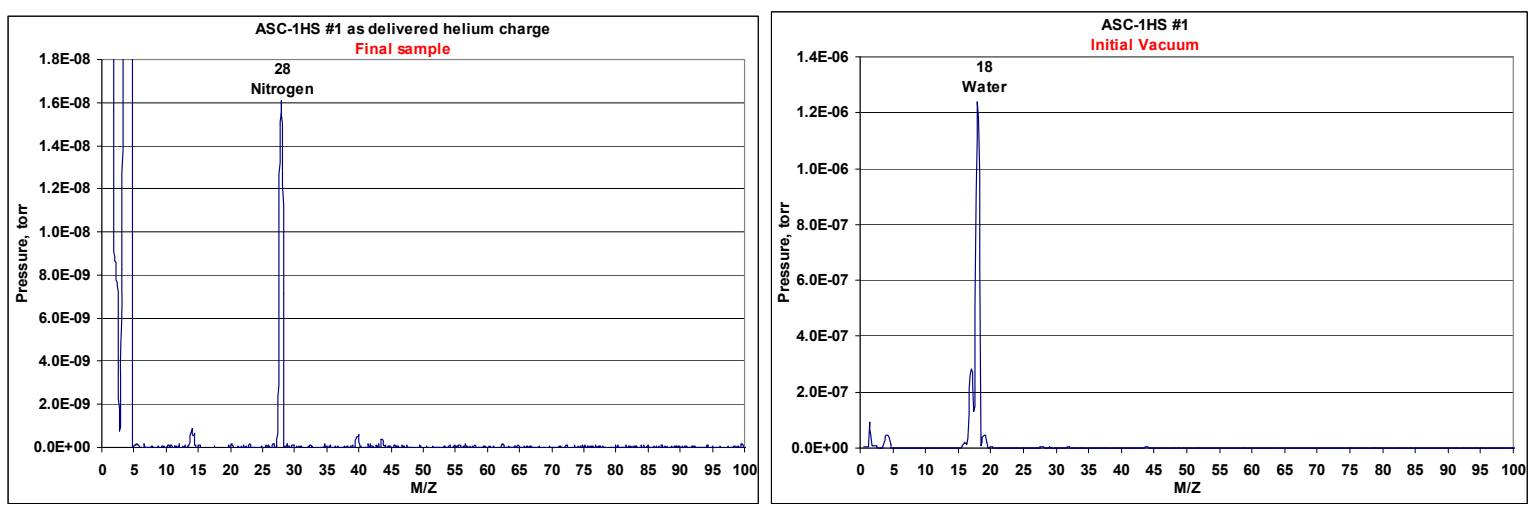

Figure 7.—ASC-1HS \#1 RGA spectra. As-delivered helium sample (left), and initial evacuation (right).

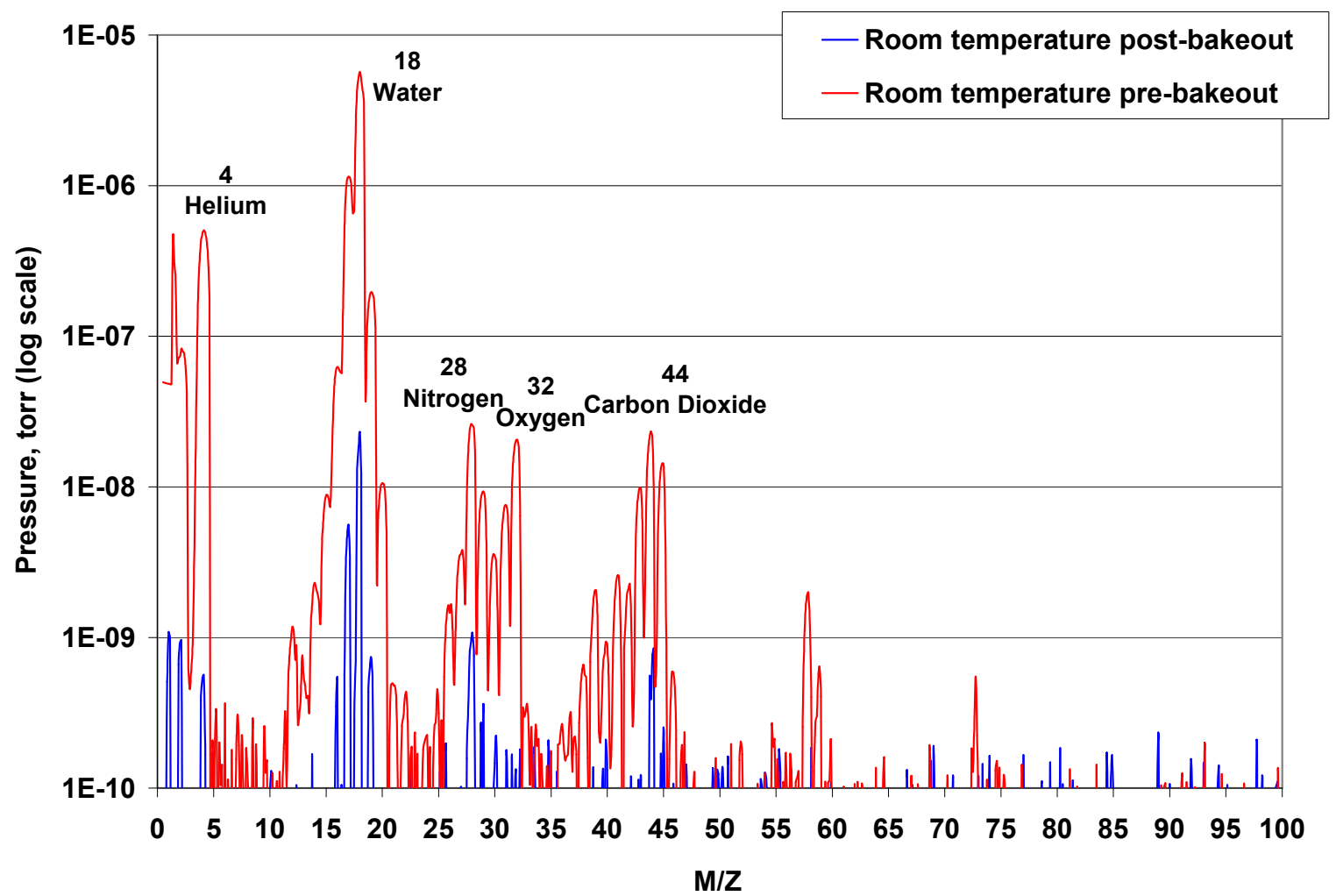

Figure 8.-ASC-1HS \#1 and \#2 pre and post bakeout room temperature RGA spectra.

samples showed only a nitrogen impurity and no presence of water. An explanation for this behavior is proposed. Sampling the helium charge only uses a small portion of the gas, so the RGA detects only a small portion of any impurities in the convertor. Since any partial pressures of impurities in the helium are small to begin with, and the sampling pressure is small (usually 5e-6 torr), the amount of impurities entering the RGA for detection may be attenuated to undetectable levels. However, when evacuating, the entire convertor volume is open to the RGA, increasing the total amount of water available for detection. Gases such as helium, nitrogen and oxygen are removed quickly, leaving the water behind. Thus, evaluating the necessity for bakeout may require more than simply sampling the helium charge.

With this knowledge, the decision was made to continue with the bakeout procedure as was performed on ASC-0 \#3 and \#4 and lasted 9.5 days. After establishing convertor vacuum at ambient temperature, the pressure was $1.9 \mathrm{e}-5$ torr. After the entirety of the bakeout effort, the pressure at room temperature was $4.3 \mathrm{e}-8$ torr. The net effect of the bakeout is illustrated in figure 11. A total of three operation stages were completed. The amount of water was reduced by more than two decades and the amount of oxygen was reduced to an undetectable level. 


\section{ASC-1 \#3 and \#4}

The nonhermetic convertors were delivered to GRC in May 2007. In lieu of a time consuming evacuation or bakeout, the convertors underwent a fill and purge operation to provide a clean helium charge. This process involved pressurizing to $3.55 \mathrm{MPa}$, then depressurizing to $0.2 \mathrm{MPa}$. This was repeated four times, followed by a final fill to the desired pressure.

Beginning in July 2007, the convertors were configured for extended operation. The hot-end thermocouples were installed using the same technique described for ASC-0 and ASC-1HS. Because of the higher operating temperature, hardware was integrated into the test article to provide an inert environment around the heat source and heater head. After evacuation was initiated the initial pressure was 1.4e-5 torr. The RGA spectrum at this point indicated water with a significant air peak. Argon was introduced into the inert environment for testing purposes and immediately appeared in the RGA spectrum. The argon container covered the heater head and main pressure vessel o-rings. The appearance of argon in the RGA spectrum suggested that the outside environment could infiltrate the inner convertor volume through these seals, limiting the effectiveness of the bakeout process. Evacuation continued and heat was applied at $75{ }^{\circ} \mathrm{C}$. Five days later, heat was removed but the pressure was only $1.7 \mathrm{e}-5$ torr, indicating no improvement. The ASC-1s were designed and built for research without provisions for extended operation. Nine Orings were used on each convertor for seals, instrumentation, and feedthroughs. Knowing that further time investment in bakeout would produce little progress, the decision was made to proceed with extended operation.

\section{Baseline Testing}

Three different tests were performed prior to extended operation to gather baseline data. First, a low-temperature checkout was performed during which the hot-end temperature was restricted to a value lower than the full design condition. The purpose of this test was to check functionality of a new test station setup and convertor pair at a conservative operating condition should any problems arise. The required rejection temperature was determined using the West temperature ratio,

$$
\mathrm{W}_{\mathrm{T}}=\frac{\mathrm{T}_{\mathrm{H}}-\mathrm{T}_{\mathrm{C}}}{\mathrm{T}_{\mathrm{H}}+\mathrm{T}_{\mathrm{C}}}
$$

where,

$\mathrm{W}_{\mathrm{T}} \quad$ West temperature ratio

$\mathrm{T}_{\mathrm{H}} \quad$ Hot-end temperature, $\mathrm{K}$

$\mathrm{T}_{\mathrm{C}} \quad$ Rejection temperature, $\mathrm{K}$

A rejection temperature was chosen to achieve the same West temperature ratio as the design condition for each convertor. All other parameters, such as piston amplitude, charge pressure, and frequency were adjusted as close as possible to the design condition. In the case of the ASC-0 and ASC-1HS convertors, the rejection hardware limited options for low-temperature checkout conditions. This was due to the configuration of the hardware that removes heat from the rejection end of the cycle. Since the minimum fluid temperature was limited to $15^{\circ} \mathrm{C}$, this limited the minimum realizable rejection temperature to approximately $50^{\circ} \mathrm{C}$. To maintain West temperature ratio during ASC0 low-temperature checkout, the hot-end temperature was raised above the $500{ }^{\circ} \mathrm{C}$ guideline to $548{ }^{\circ} \mathrm{C}$. In the case of the high temperature ASC-1HSs, low-temperature checkout was performed using a $650{ }^{\circ} \mathrm{C}$ hot-end and a $50{ }^{\circ} \mathrm{C}$ rejection.

Once low-temperature checkout was completed, full-temperature and power demonstrations followed. During this test, the convertors were operated at their full design hot-end and rejection temperatures. Other parameters, such as charge pressure and piston amplitude, were also adjusted to full design conditions. This test provided a data point for comparison to performance data that were recorded prior to delivery, as well as during extended operation.

An insulation loss characterization was performed on ASC-0 \#1 through \#4, and on ASC-1 \#3 and \#4. No insulation loss characterization was performed on ASC-1HS \#1 and \#2. Insulation loss characterization was required to determine a correlation between operating temperatures and the portion of thermal input that does not reach the convertor. The thermal energy loss through the insulation was subtracted from the gross thermal energy input to calculate net heat input and thus net conversion efficiency. The procedure consisted of evacuating the convertor while measuring thermal input required to maintain each point in a matrix of hot-end and rejection temperatures. Since in this case the working fluid was absent, no energy was drawn by a thermodynamic cycle. All thermal input 
was either lost through the insulation or conducted and radiated down the heater head. The heat transfer through the heater head was calculated using heat transfer equations and subtracted from the total thermal input at each point to determine the insulation loss. A plane fit was then performed to generate an equation relating insulation loss to the hot-end and rejection temperatures. The matrix of temperatures used during the test depended on the type of convertor and its associated maximum hot-end temperature. Table III summarizes the temperatures used for thermal loss characterization.

TABLE III.-INSULATION LOSS CHARACTERIZATION TEMPERATURE MATRICES

\begin{tabular}{|c|c|c|c|}
\hline \multicolumn{2}{|c|}{ ASC-0 } & \multicolumn{2}{c|}{ ASC-1 and ASC-1HS } \\
\hline $\begin{array}{c}\text { Hot-end temperature } \\
{ }^{\circ} \mathrm{C}\end{array}$ & $\begin{array}{c}\text { Rejection temperature } \\
{ }^{\circ} \mathrm{C}\end{array}$ & $\begin{array}{c}\text { Hot-end temperature } \\
{ }^{\circ} \mathrm{C}\end{array}$ & $\begin{array}{c}\text { Rejection temperature } \\
{ }^{\circ} \mathrm{C}\end{array}$ \\
\hline 550 & 60 & 650 & 60 \\
\hline 650 & 60 & 850 & 60 \\
\hline 550 & 90 & 650 & 90 \\
\hline 650 & 90 & 850 & 90 \\
\hline
\end{tabular}

\section{A. ASC-0 \#1 and \#2}

The low-temperature checkout of these convertors was completed February 2007. The heat rejection hardware limited the rejection temperature to no less than $50^{\circ} \mathrm{C}$, which required a hot-end temperature of $548{ }^{\circ} \mathrm{C}$ to maintain West temperature ratio. Full-temperature demonstration was completed the same day at a hot-end temperature of $650{ }^{\circ} \mathrm{C}$ and a rejection temperature of $90{ }^{\circ} \mathrm{C}$. Table IV summarizes the results of the low-temperature checkout and full-temperature demonstration.

TABLE IV.-ASC-0 \#1 AND \#2 LOW-TEMPERATURE CHECKOUT AND FULL-TEMPERATURE DEMONSTRATION RESULTS

\begin{tabular}{|l|c|c|c|c|c|}
\hline & & \multicolumn{2}{c|}{ Low-temperature checkout } & \multicolumn{2}{c|}{ Full-temperature demonstration } \\
\hline \multicolumn{1}{|c|}{ Parameter } & Units & ASC-0 \#1 & ASC-0 \#2 & ASC-0 \#1 & ASC-0 \#2 \\
\hline Average hot-end temperature & ${ }^{\circ} \mathrm{C}$ & 547.8 & 547.7 & 645.5 & 645.1 \\
\hline Rejection temperature & ${ }^{\circ} \mathrm{C}$ & 50.3 & 49.2 & 90.3 & 88.4 \\
\hline Pressure vessel temperature & ${ }^{\circ} \mathrm{C}$ & 50.7 & 50.9 & 82.1 & 83.2 \\
\hline Gross heat input & $\mathrm{W}_{\mathrm{th}}$ & 281.6 & 279.3 & 313.1 & 304.2 \\
\hline Net heat input & $\mathrm{W}_{\mathrm{th}}$ & 233.9 & 232.1 & 247.5 & 239.4 \\
\hline Gross efficiency & $\%$ & 23.0 & 22.8 & 22.0 & 21.3 \\
\hline Net efficiency & $\%$ & 27.6 & 27.5 & 27.8 & 27.1 \\
\hline Alternator voltage & $\mathrm{V}_{\mathrm{rms}}$ & 27.19 & 27.20 & 26.95 & 26.96 \\
\hline Alternator current & $\mathrm{A}_{\mathrm{rms}}$ & 2.83 & 2.77 & 3.01 & 2.82 \\
\hline Alternator power output & $\mathrm{W}$ & 64.65 & 63.74 & 68.91 & 64.78 \\
\hline Charge pressure & $\mathrm{MPa}$ & 3.556 & 3.541 & 3.549 & 3.547 \\
\hline Piston amplitude & $\mathrm{mm}$ & 4.42 & 4.50 & 4.42 & 4.48 \\
\hline Operating frequency & $\mathrm{Hz}$ & 103.9 & 103.9 & 103.7 & 103.7 \\
\hline
\end{tabular}

After completing the full-temperature demonstration, the convertors continued operation at these conditions and extended in-air operation began. This continued for $600 \mathrm{hr}$ until shutdown for transition to thermal vacuum operation. Since the thermal loss characterization had not been completed, this test was performed before removing the convertors from the test station. Data were recorded at hot-end temperatures of 650 and $550{ }^{\circ} \mathrm{C}$, and at rejection temperatures of 90 and $60^{\circ} \mathrm{C}$. The results are summarized in table V. From these data points the following equations were generated:

$$
\begin{aligned}
& \text { ASC-0 \#1: } Q_{\text {loss }}=0.187 \mathrm{~T}_{\mathrm{H}}-0.0093 \mathrm{~T}_{\mathrm{C}}-54.31 \\
& \text { ASC-0 \#2: } \mathrm{Q}_{\text {loss }}=0.182 \mathrm{~T}_{\mathrm{H}}-0.0037 \mathrm{~T}_{\mathrm{C}}-52.25
\end{aligned}
$$


TABLE V.-ASC-0 \#1 AND \#2 THERMAL LOSS CHARACTERIZATION RESULTS

\begin{tabular}{|c|c|c|c|c|}
\hline \multicolumn{5}{|c|}{ ASC- $0 \# 1$} \\
\hline $\begin{array}{c}\text { Hot-end temperature } \\
\left(\mathrm{T}_{\mathrm{H}}\right) \\
{ }^{\circ} \mathrm{C}\end{array}$ & $\begin{array}{c}\text { Rejection temperature } \\
\left(\mathrm{T}_{\mathrm{C}}\right) \\
{ }^{\circ} \mathrm{C}\end{array}$ & $\begin{array}{c}\text { Heater power } \\
\text { W }\end{array}$ & $\begin{array}{l}\text { Heater head heat transfer } \\
\text { W }\end{array}$ & $\begin{array}{c}\text { Insulation loss } \\
\left(\mathrm{Q}_{\text {loss }}\right) \\
\text { W }\end{array}$ \\
\hline 548.5 & 60.6 & 57.9 & 10.2 & 47.7 \\
\hline 647.9 & 60.0 & 79.5 & 13.2 & 66.3 \\
\hline 548.7 & 89.7 & 57.1 & 9.6 & 47.5 \\
\hline 648.0 & 90.3 & 78.8 & 12.5 & 66.3 \\
\hline \multicolumn{5}{|c|}{ ASC- $0 \# 2$} \\
\hline $\begin{array}{c}\text { Hot-end temperature } \\
\left(\mathrm{T}_{\mathrm{H}}\right) \\
{ }^{\circ} \mathrm{C} \\
\end{array}$ & $\begin{array}{c}\text { Rejection temperature } \\
\left(\mathrm{T}_{\mathrm{C}}\right) \\
{ }^{\circ} \mathrm{C} \\
\end{array}$ & $\begin{array}{c}\text { Heater power } \\
\text { W }\end{array}$ & $\begin{array}{l}\text { Heater head heat transfer } \\
\text { W }\end{array}$ & $\begin{array}{c}\text { Insulation loss } \\
\left(\mathrm{Q}_{\text {loss }}\right) \\
\mathrm{W} \\
\end{array}$ \\
\hline 547.4 & 60.2 & 57.0 & 10.1 & 46.9 \\
\hline 646.5 & 59.5 & 78.1 & 13.2 & 64.9 \\
\hline 547.5 & 88.9 & 56.4 & 9.5 & 46.8 \\
\hline 646.6 & 89.5 & 77.3 & 12.4 & 64.9 \\
\hline
\end{tabular}

where,

Q

$\mathrm{T}_{\mathrm{H}} \quad$ Hot-end temperature, ${ }^{\circ} \mathrm{C}$

$\mathrm{T}_{\mathrm{C}} \quad$ Rejection temperature, ${ }^{\circ} \mathrm{C}$

These equations were applied retroactively to calculate insulation loss and net efficiency at each data point during the $600 \mathrm{hr}$ of extended in-air operation. During full-temperature operation, the insulation package performed with an efficiency of approximately 79 percent.

\section{B. ASC-0 \#3 and \#4}

Thermal loss characterization was completed on these convertors in parallel with the bakeout process. Data were recorded at hot-end temperatures of 650 and $550{ }^{\circ} \mathrm{C}$, and at rejection temperatures of 90 and $60{ }^{\circ} \mathrm{C}$. The results are summarized in table VI.

TABLE VI.-ASC-0 \#3 AND \#4 THERMAL LOSS CHARACTERIZATION RESULTS

\begin{tabular}{|c|c|c|c|c|}
\hline \multicolumn{5}{|c|}{ ASC-0 \#3 } \\
\hline $\begin{array}{l}\text { Hot-end temperature } \\
\left(\mathrm{T}_{\mathrm{H}}\right) \\
{ }^{\circ} \mathrm{C}\end{array}$ & $\begin{array}{l}\text { Rejection temperature } \\
\left(\begin{array}{c}\left(\mathrm{T}_{\mathrm{C}}\right) \\
{ }^{\circ} \mathrm{C}\end{array}\right.\end{array}$ & $\begin{array}{c}\text { Heater power } \\
\text { W }\end{array}$ & $\begin{array}{c}\text { Heater head heat transfer } \\
\text { W }\end{array}$ & $\begin{array}{c}\text { Insulation loss } \\
\left(\mathrm{Q}_{\text {loss }}\right) \\
\mathrm{W}\end{array}$ \\
\hline 550.1 & 60.1 & 57.6 & 10.2 & 47.4 \\
\hline 649.2 & 60.2 & 78.8 & 13.2 & 65.6 \\
\hline 549.9 & 90.2 & 57.2 & 9.6 & 47.6 \\
\hline 649.2 & 90.6 & 78.5 & 12.5 & 66.0 \\
\hline \multicolumn{5}{|c|}{ ASC- 0 \#4 } \\
\hline $\begin{array}{c}\text { Hot-end temperature } \\
\left(\mathrm{T}_{\mathrm{H}}\right) \\
{ }^{\circ} \mathrm{C} \\
\end{array}$ & $\begin{array}{c}\text { Rejection temperature } \\
\left(\mathrm{T}_{\mathrm{C}}\right) \\
{ }^{\circ} \mathrm{C} \\
\end{array}$ & $\begin{array}{c}\text { Heater power } \\
\mathrm{W}\end{array}$ & $\begin{array}{c}\text { Heater head heat transfer } \\
\text { W }\end{array}$ & $\begin{array}{c}\text { Insulation loss } \\
\left(\mathrm{Q}_{\text {loss }}\right) \\
\text { W }\end{array}$ \\
\hline 550.6 & 59.8 & 57.2 & 10.2 & 46.9 \\
\hline 646.6 & 59.8 & 77.6 & 13.1 & 64.4 \\
\hline 550.5 & 89.9 & 57.0 & 9.6 & 47.4 \\
\hline 646.7 & 90.2 & 77.2 & 12.4 & 64.7 \\
\hline
\end{tabular}

These data were used to generate the following equations:

$$
\begin{aligned}
& \text { ASC-0 \#3: } \mathrm{Q}_{\text {loss }}=0.183 \mathrm{~T}_{\mathrm{H}}-0.0068 \mathrm{~T}_{\mathrm{C}}-53.75 \\
& \text { ASC-0 \#4: } \mathrm{Q}_{\text {loss }}=0.182 \mathrm{~T}_{\mathrm{H}}-0.0169 \mathrm{~T}_{\mathrm{C}}-54.51
\end{aligned}
$$

The insulation package on these convertors was identical to that implemented on ASC-0 \#1 and \#2, thus the results were similar. 
The low-temperature checkout of these convertors was completed in September 2007. The same design of rejection hardware was used on both pairs of ASC-0s thus limiting the rejection temperature to no less than $50{ }^{\circ} \mathrm{C}$, which required a hot-end temperature of $548^{\circ} \mathrm{C}$ to maintain West temperature ratio. Full-temperature demonstration was completed in October 2007 at a hot-end temperature of $650{ }^{\circ} \mathrm{C}$ and a rejection temperature of $90{ }^{\circ} \mathrm{C}$. Table VII summarizes the results of the low-temperature checkout and full-temperature demonstration.

\begin{tabular}{|c|c|c|c|c|c|}
\hline \multirow[b]{2}{*}{ Parameter } & \multirow[b]{2}{*}{ Units } & \multicolumn{2}{|c|}{ Low-temperature checkout } & \multicolumn{2}{|c|}{ Full-temperature demonstration } \\
\hline & & ASC-0 \#3 & ASC-0 \#4 & ASC-0 \#3 & ASC-0 \#4 \\
\hline Average hot-end temperature & ${ }^{\circ} \mathrm{C}$ & 548.4 & 547.8 & 644.4 & 644.3 \\
\hline Rejection temperature & ${ }^{\circ} \mathrm{C}$ & 50.1 & 50.0 & 89.6 & 89.9 \\
\hline Pressure vessel temperature & ${ }^{\circ} \mathrm{C}$ & 48.6 & 49.8 & 78.8 & 82.0 \\
\hline Gross heat input & $\mathrm{W}_{\text {th }}$ & 291.1 & 293.3 & 323.3 & 326.3 \\
\hline Net heat input & $\mathrm{W}_{\text {th }}$ & 244.1 & 247.3 & 258.4 & 261.7 \\
\hline Gross efficiency & $\%$ & 24.8 & 24.5 & 23.2 & 23.0 \\
\hline Net efficiency & $\%$ & 29.6 & 29.1 & 29.1 & 28.6 \\
\hline Alternator voltage & $\mathrm{V}_{\mathrm{rms}}$ & 22.4 & 22.4 & 21.4 & 21.4 \\
\hline Alternator current & $\mathrm{A}_{\mathrm{rms}}$ & 3.2 & 3.2 & 3.5 & 3.5 \\
\hline Alternator power output & $\mathrm{W}_{\mathrm{e}}$ & 72.2 & 72.0 & 75.1 & 74.9 \\
\hline Charge pressure & $\mathrm{MPa}$ & 3.554 & 3.550 & 3.558 & 3.552 \\
\hline Piston amplitude & $\mathrm{mm}$ & 4.50 & 4.37 & 4.49 & 4.38 \\
\hline Operating frequency & $\mathrm{Hz}$ & 104.2 & 104.2 & 104.2 & 104.2 \\
\hline
\end{tabular}

\section{ASC-1HS \#1 and \#2}

Operation of these convertors at the low-temperature condition was initiated in February 2008. As with the ASC0 s, the rejection temperature was limited to $50{ }^{\circ} \mathrm{C}$. Since the design hot-end temperature was $850{ }^{\circ} \mathrm{C}$, maintaining the West temperature ratio at $50{ }^{\circ} \mathrm{C}$ rejection would require a hot-end temperature of $726^{\circ} \mathrm{C}$. The West temperature ratio requirement was relaxed in favor of operating at a more conservative hot-end temperature. As such, the lowtemperature operating conditions were altered to $650{ }^{\circ} \mathrm{C}$ hot-end and $50^{\circ} \mathrm{C}$ rejection. Operation at these conditions continued for $127 \mathrm{hr}$, at which time the operating point was adjusted to full design temperature of $850^{\circ} \mathrm{C}$ hot-end and $90{ }^{\circ} \mathrm{C}$ rejection. Table VIII summarizes the results of both the low-temperature checkout and full-temperature demonstration. As stated earlier, no insulation loss characterization was performed on the ASC-1HSs, so values for net heat input and net efficiency are not included.

TABLE VIII.-ASC-1HS \#1 AND \#2 LOW-TEMPERATURE AND FULL-TEMPERATURE RESULTS

\begin{tabular}{|l|c|c|c|c|c|}
\hline & & \multicolumn{2}{|c|}{ Low-temperature checkout } & \multicolumn{2}{c|}{ Full-temperature demonstration } \\
\hline \multicolumn{1}{|c|}{ Parameter } & Units & ASC-1HS \#1 & ASC-1HS \#2 & ASC-1HS \#1 & ASC-1HS \#2 \\
\hline Average hot-end temperature & ${ }^{\circ} \mathrm{C}$ & 650.1 & 649.7 & 838.1 & 841.1 \\
\hline Rejection temperature & ${ }^{\circ} \mathrm{C}$ & 51.0 & 51.9 & 89.5 & 90.3 \\
\hline Pressure vessel temperature & ${ }^{\circ} \mathrm{C}$ & 51.2 & 50.3 & 83.2 & 81.9 \\
\hline Gross heat input & $\mathrm{W}_{\text {th }}$ & 332.8 & 320.3 & 425.8 & 406.2 \\
\hline Gross efficiency & $\%$ & 24.3 & 24.0 & 22.8 & 23.1 \\
\hline Alternator voltage & $\mathrm{V}_{\mathrm{rms}}$ & 24.04 & 24.09 & 23.34 & 23.41 \\
\hline Alternator current & $\mathrm{A}_{\mathrm{rms}}$ & 3.46 & 3.26 & 4.30 & 4.10 \\
\hline Alternator power output & $\mathrm{W}_{\mathrm{e}}$ & 80.69 & 76.97 & 96.98 & 93.73 \\
\hline Charge pressure & $\mathrm{MPa}$ & 3.565 & 3.550 & 3.535 & 3.538 \\
\hline Piston amplitude & $\mathrm{mm}$ & 4.47 & 4.20 & 4.49 & 4.22 \\
\hline Operating frequency & $\mathrm{Hz}$ & 102.0 & 102.0 & 102.0 & 102.0 \\
\hline
\end{tabular}




\section{ASC-1 \#3 and \#4}

Operation of these convertors was initiated in May 2007. Since these convertors were designed for $850{ }^{\circ} \mathrm{C}$ hotend and $90^{\circ} \mathrm{C}$ rejection, the low-temperature checkout was performed at $650{ }^{\circ} \mathrm{C}$ hot-end and $25^{\circ} \mathrm{C}$ rejection. Helium leakage from the convertors did not permit continuous operation. To accumulate hours, the convertors were operated in attended mode. Operation at the low-temperature condition continued for $260 \mathrm{hr}$, after which an automated helium regulator was connected to the helium management system. This permitted continuous operation. Operation at $850{ }^{\circ} \mathrm{C}$ hot-end was achieved in November, 2007. Table IX summarizes the results of the low-temperature and full-temperature tests. The insulation loss characterization was performed in December 2007. The results of the insulation loss characterization are contained in Table X. Correlations for conduction through the high temperature heater heads have not yet been developed, so the insulation loss and net efficiency still remain to be determined for the ASC-1 data.

TABLE IX.-ASC-1 \#3 AND \#4 LOW-TEMPERATURE CHECKOUT AND FULL-TEMPERATURE DEMONSTRATION TEST RESULTS

\begin{tabular}{|c|c|c|c|c|c|}
\hline \multirow[b]{2}{*}{ Parameter } & \multirow[b]{2}{*}{ Units } & \multicolumn{2}{|c|}{ Low-temperature checkout } & \multicolumn{2}{|c|}{ Full-temperature demonstration } \\
\hline & & ASC-1 \#3 & ASC-1 \#4 & ASC-1 \#3 & ASC-1 \#4 \\
\hline Average hot-end temperature & ${ }^{\circ} \mathrm{C}$ & 649.0 & 648.6 & 844.0 & 844.0 \\
\hline Rejection temperature & ${ }^{\circ} \mathrm{C}$ & 25.2 & 24.0 & 89.3 & 89.7 \\
\hline Pressure vessel temperature & ${ }^{\circ} \mathrm{C}$ & 48.6 & 48.6 & 88.2 & 83.4 \\
\hline Gross heat input & $\mathrm{W}_{\text {th }}$ & 311.7 & 305.6 & 396.0 & 300.5 \\
\hline Gross efficiency & $\%$ & 21.9 & 21.2 & 17.9 & 18.9 \\
\hline Alternator voltage & $\mathrm{V}_{\mathrm{rms}}$ & 9.51 & 9.63 & 7.77 & 7.85 \\
\hline Alternator current & $\mathrm{A}_{\mathrm{rms}}$ & 7.37 & 6.64 & 8.72 & 6.97 \\
\hline Alternator power output & $\mathrm{W}_{\mathrm{e}}$ & 68.2 & 64.7 & 71.0 & 56.8 \\
\hline Charge pressure & $\mathrm{MPa}$ & 3.514 & 3.563 & 3.518 & 3.540 \\
\hline Piston amplitude & $\mathrm{mm}$ & 4.48 & 4.13 & 4.51 & 3.84 \\
\hline Operating frequency & $\mathrm{Hz}$ & 103.1 & 103.1 & 103.0 & 103.0 \\
\hline
\end{tabular}

TABLE X.-ASC-1 \#3 AND \#4 THERMAL LOSS CHARACTERIZATION RESULTS

\begin{tabular}{|c|c|c|}
\hline \multicolumn{3}{|c|}{ ASC-1 \#3 } \\
\hline $\begin{array}{l}\text { Hot-end temperature } \\
\qquad\left(\mathrm{T}_{\mathrm{H}}\right) \\
{ }^{\circ} \mathrm{C}\end{array}$ & $\begin{array}{c}\text { Rejection temperature, } \\
\left(\mathrm{T}_{\mathrm{C}}\right) \\
{ }^{\circ} \mathrm{C}\end{array}$ & $\begin{array}{c}\text { Heater power } \\
\text { W }\end{array}$ \\
\hline 649.6 & 60.1 & 58.3 \\
\hline 845.4 & 59.7 & 101.2 \\
\hline 649.7 & 89.4 & 55.6 \\
\hline 845.3 & 90.0 & 101.2 \\
\hline \multicolumn{3}{|c|}{ ASC-1 \#4 } \\
\hline $\begin{array}{l}\text { Hot-end temperature } \\
\qquad\left(\mathrm{T}_{\mathrm{H}}\right) \\
{ }^{\circ} \mathrm{C} \\
\end{array}$ & $\begin{array}{l}\text { Rejection temperature } \\
\qquad\left(\mathrm{T}_{\mathrm{C}}\right) \\
{ }^{\circ} \mathrm{C} \\
\end{array}$ & $\begin{array}{c}\text { Heater power } \\
\text { W }\end{array}$ \\
\hline 649.9 & 60.6 & 56.3 \\
\hline 847.0 & 60.9 & 100.9 \\
\hline 650.0 & 89.0 & 55.5 \\
\hline 847.1 & 90.3 & 100.3 \\
\hline
\end{tabular}

The insulation package was redesigned for the ASC-1s since it was thought that the higher hot-end operating temperature would result in higher than desired losses if the original ASC-0 design were used. The overall insulation diameter was increased one inch from 5.75 to 6.75 in. This change reduced the heater power required to maintain $650^{\circ} \mathrm{C}$ by 17 percent.

\section{Conclusion}

A summary of processing of eight ASCs at GRC has been presented. Some form of bakeout was performed on each convertor to provide a pure environment for helium fill. The bakeout process evolved and was improved as knowledge and experience was gathered. A new bakeout process is now in place that incorporates stages of convertor operation in addition to evacuation with applied heat. Baseline testing was performed on each convertor 
first at an intermediate hot-end temperature and then at full design conditions. Six convertors also underwent a process to characterize their insulation losses. This process provided data that was used to calculate net conversion efficiency during baseline and extended operation. These test provided data used for acceptance of the delivered hardware, and will also be used for comparison during extended operation.

\section{References}

1. Chan, J., "Development of Advanced Stirling Radioisotope Generator for Space Exploration," Proceedings of Space Technology and Applications International Forum (STAIF-2007), edited by M.S. El-Genk, Albuquerque, NM, 2007.

2. Schreiber, J.G., "Final Results for the GRC Supporting Technology Development for the 110-Watt Stirling Radioisotope Generator (SRG110)," Proceedings of Space Technology and Applications International Forum (STAIF-2007), edited by M.S. El-Genk, Albuquerque, NM, 2007.

3. Schreiber, J.G., "Summary of Stirling Convertor Testing at GRC," Proceedings of 4th International Energy Conversion Engineering Conference, San Diego, CA, 2006, AIAA-2006-4061.

4. Wood, J.G., "Advanced Stirling Convertor Phase II Achievements and Planned Phase III Effort," Proceedings of 4th International Energy Conversion Engineering Conference, San Diego, CA, 2006, AIAA-2006-4108.

5. Schreiber, J.G., Roth, M., and Pepper, S.V., "Extended Operation of Stirling Convertors," Proceedings of 2nd International Energy Conversion Engineering Conference, Providence, RI, 2004, AIAA-2004-5508.

6. Oriti, S.M., "Update on Extended Operation of Stirling Convertors in Thermal Vacuum at NASA Glenn Research Center," Proceedings of 4th International Energy Conversion Engineering Conference, San Diego, CA, 2006, AIAA-2006-4062, NASA/TM-2006-214424.

7. Wood, J.G., "Continued Development of the Advanced Stirling Convertor," Proceedings of 5th International Energy Conversion Engineering Conference), St. Louis, MO, 2007, AIAA-2007-4704. 


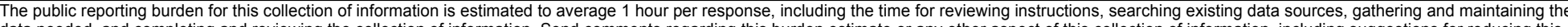

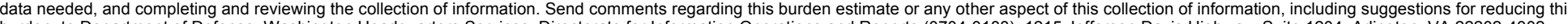

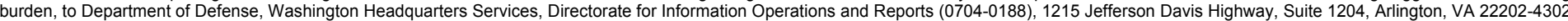

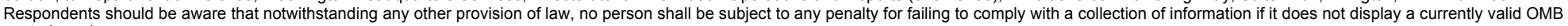
control number.

PLEASE DO NOT RETURN YOUR FORM TO THE ABOVE ADDRESS.

\section{REPORT DATE (DD-MM-YYYY) \\ 2. REPORT TYPE \\ 3. DATES COVERED (From - To)}

01-12-2008

\section{TITLE AND SUBTITLE}

Technical Memorandum

Processing and Preparation of Advanced Stirling Convertors for Extended Operation at

NASA Glenn Research Center

5a. CONTRACT NUMBER

5b. GRANT NUMBER

5c. PROGRAM ELEMENT NUMBER

6. AUTHOR(S)

Oriti, Salvatore, M.; Cornell, Peggy, A.

\section{5d. PROJECT NUMBER}

5e. TASK NUMBER

5f. WORK UNIT NUMBER

WBS 138494.04.01.01

8. PERFORMING ORGANIZATION

REPORT NUMBER

E-16645

National Aeronautics and Space Administration

John H. Glenn Research Center at Lewis Field

Cleveland, Ohio 44135-3191

9. SPONSORING/MONITORING AGENCY NAME(S) AND ADDRESS(ES)

National Aeronautics and Space Administration

Washington, DC 20546-0001

\begin{tabular}{l} 
10. SPONSORING/MONITORS \\
ACRONYM(S) \\
NASA \\
\hline $\begin{array}{l}\text { 11. SPONSORING/MONITORING } \\
\text { REPORT NUMBER } \\
\text { NASA/TM-2008-215454 }\end{array}$
\end{tabular}

\section{DISTRIBUTION/AVAILABILITY STATEMENT}

Unclassified-Unlimited

Subject Category: 20

Available electronically at http://gltrs.grc.nasa.gov

This publication is available from the NASA Center for AeroSpace Information, 301-621-0390

\section{SUPPLEMENTARY NOTES}

\section{ABSTRACT}

The U.S. Department of Energy (DOE), Lockheed Martin Space Company (LMSC), Sunpower Inc., and NASA Glenn Research Center (GRC) have been developing an Advanced Stirling Radioisotope Generator (ASRG) for use as a power system on space science missions. This generator will make use of the free-piston Stirling convertors to achieve higher conversion efficiency than currently available alternatives. NASA GRC is supporting the development of the ASRG by providing extended operation of several Sunpower Inc. Advanced Stirling Convertors (ASCs). In the past year and a half, eight ASCs have operated in continuous, unattended mode in both air and thermal vacuum environments. Hardware, software, and procedures were developed to prepare each convertor for extended operation with intended durations on the order of tens of thousands of hours. Steps taken to prepare a convertor for long-term operation included geometry measurements, thermocouple instrumentation, evaluation of working fluid purity, evacuation with bakeout, and high purity charge. Actions were also taken to ensure the reliability of support systems, such as data acquisition and automated shutdown checkouts. Once a convertor completed these steps, it underwent short-term testing to gather baseline performance data before initiating extended operation. These tests included insulation thermal loss characterization, low-temperature checkout, and full-temperature and power demonstration. This paper discusses the facilities developed to support continuous, unattended operation, and the processing results of the eight ASCs currently on test. 15. SUBJECT TERMS

Advanced Stirling convertor; Advanced Stirling radioisotope generator; General purpose heat source; Proportional; Integral; Derivative residual gas analyzer; Radioisotope thermoelectric generator; Technology demonstration convertor

\begin{tabular}{|c|c|c|c|c|c|}
\hline \multicolumn{3}{|c|}{ 16. SECURITY CLASSIFICATION OF: } & \multirow{2}{*}{$\begin{array}{l}\text { 17. LIMITATION OF } \\
\text { ABSTRACT } \\
\text { UU }\end{array}$} & \multirow{2}{*}{$\begin{array}{l}\text { 18. NUMBER } \\
\text { OF } \\
\text { PAGES } \\
22\end{array}$} & \multirow{2}{*}{$\begin{array}{l}\text { 19a. NAME OF RESPONSIBLE PERSON } \\
\text { STI Help Desk (email:help@sti.nasa.gov) } \\
\text { 19b. TELEPHONE NUMBER (include area code) } \\
\text { 301-621-0390 }\end{array}$} \\
\hline $\begin{array}{l}\text { a. REPORT } \\
\text { U }\end{array}$ & $\begin{array}{l}\text { b. ABSTRACT } \\
U\end{array}$ & $\begin{array}{l}\text { c. THIS } \\
\text { PAGE } \\
U\end{array}$ & & & \\
\hline
\end{tabular}



